\title{
STUDY OF BIOMASS UTILISATION IN THE IRON ORE SINTERING
}

\author{
Lina Kieush $^{()^{*}}$, Maksym Yaholnyk ${ }^{1)}$, Maksym Boyko ${ }^{1)}$, Andrii Koveria ${ }^{2)}$, Vladyslav Ihnatenko ${ }^{1)}$ \\ 1) National Metallurgical Academy of Ukraine, Department of Iron Metallurgy, Dnipro, Ukraine \\ 2) National Technical University "Dnipro Polytechnic”, Department of Chemistry, Dnipro, \\ Ukraine
}

Received: 17.02.2019

Accepted: 08.03.2019

${ }^{*}$ Corresponding author: e-mail: linakeush@gmail.com, Tel.: +380681768583, National Metallurgical Academy of Ukraine, Department of Iron Metallurgy, Dnipro, Ukraine

\begin{abstract}
Dominating globally and within Ukraine, the blast-furnace practice for iron production requires iron ore sintering preparation wherein the significant amount of fossil fuel is consumed, accompanied by harmful emissions into the environment. Pursuing the purpose to mitigate this negative impact, we address the promising direction of biomass utilisation for a partial replacement of fossil fuels in iron ore sintering. This paper considers the benefits of fossil fuels substitution with biomass, the world practice of biomass utilisation in iron ore sintering and the scope of the biomass energy potential in Ukraine. The study for obtaining sinters with the use of raw biomass fuels (sunflower husk, walnut shell) and charcoal has been carried out via lab-scale sintering pot. The influence of various biomaterials types on the process of iron ore sintering have been investigated and the obtained sinter quality in comparison with the conventional types of the fuels allows establishing the feasibility of replacing $25 \%$ of coke breeze by charcoal or by walnut shell. The sunflower husk application is possible if preliminary preparation of the material for increasing bulk density is assumed to be carried out, for instance, by pressing.
\end{abstract}

Keywords: iron ore sintering, biomass; sinter, walnut shell, sunflower husk, charcoal

\section{Introduction}

Steel production in 2017 amounted approximately 1691.2 million tons, and according to the reported demand [1], in the nearest future this production will increasingly grow. Meanwhile, higher prices on conventional energy resources and their negative impact on the environment increase the share of renewable energy in the world. The use of biomass for energy based on contemporary technology is environmentally safer than the use of conventional energy from nonrenewable sources such as coal. An important aspect is that the transition from fossil fuel sources to renewable sources will be more efficient through the use of local resources and already existing infrastructure [2-5].

One of the most promising types of renewable energy sources is biomass, which occupies the fourth place among fuels by value. Biomass is the only energy in the nature that contains a carbon resource in a fairly large quantity to be effectively used as a substitution of fossil fuels. Annually, biomass accounts for about 1.4 billion toe, which is about $14 \%$ of the total primary energy consumption in the world. In the EU energy plans, the task is to increase the share of the energy produced from renewable energy sources in gross final energy consumption of up to $20 \%$ by 2020 , including those from biomass of up to $14 \%$. The same indicator in 2030 should be of $27 \%$ [6].

According to the Bioenergy Association of Ukraine, the total potential of biomass energy was 20.2 million toe in 2015. The main constituents of this potential were the by-products of crop 
production (straw of cereals and rapeseeds, corn stalks, sunflower, etc.) with the share of $37.6 \%$ and energy crops (willow, poplar, miscanthus) of $39 \%$ [7]. However, according to the State Statistics Service of Ukraine, the total supply of primary energy from biomass was only $2.2 \%$ in the same 2015. Apparently, finding the ways to increase the share of biomass utilisation is becoming an urgent task since there is a significant reserve to increase the energy benefits from the biomass concentrated in the industries, the main consumers of energy resources. One of such industries is metallurgy.

The world`s specialised scientific laboratories have been actively exploring the use of biomass instead of fossil fuels in various metallurgical processes over the last decade. The ways of utilisation for the biomass and the products of its processing in metallurgy are discussed in detail in works [8-11]. It is shown that, the use of biomass in metallurgical industries is complex in terms of scientific, technological and economic issues. Most important route for steel production is blast furnace/basic oxygen furnace (BF-BOF). The BF-BOF route represents about $70 \%$ of the world steel production and, respectively, is the most fuel dependent. Therefore, the most effective approach in terms of $\mathrm{CO}_{2}$ mitigation and the replacement of conventional fuels and reducing agents can be considered the biomass utilisation in blast furnace ironmaking [12-16].

A number of works had been carried out over the efficiency issues of biomass application in the process of iron ore sintering. Ooi et al. [17] studied in detail the use of sunflower husks as an additional fuel incorporated in iron ore sintering. It was established that when replacing $10 \%$ of coke breeze with the sunflower husk in sintering, there were no significant changes observed either in the combustion characteristics of the thereof process or in sinter quality. The use of charcoal instead of coke or coal during iron ore sintering increased the sintering velocity. This increase was explained to depend on the type of the biomass source and its share in the fuel component.

Generally, the efficiency of charcoal adding is known to be dependent on its origin and is reduced as follows: straw $>$ wood $>$ peat. Furthermore, the biomass addition reduces the maximum temperature of the layer of the materials being sintered and the time to achieve the maximum sintering temperature, and additionally it allows the expansion of sintering temperature range [18, 19]. It is important to note here that the changes in the combustion conditions and the gasification velocity produced by biomass application does not contribute to the formation of liquid calcium ferrite. This leads to the decrease in the sinter strength due to a smaller proportion of calcium ferrite in the mineralogical structure of the sinter $[18,20]$. The same conclusion is made by Wei et al. [9], who indicates that, regardless the biomass type and its amount, the yield of the resulting sinter and its strength are reduced when the biomass participates in the sintering process. The possible mechanism for correcting the sintering process is the change in the size and the amount of the biomass, the amount of wind, as well as the properties of the biomass.

Generally, iron ore sintering is the source of a large number of harmful emissions, namely $\mathrm{CO}$, $\mathrm{CO}_{2}, \mathrm{SO}_{2}, \mathrm{NO}_{\mathrm{x}}$ and organic compounds [21-24]. Further, it has been established that the addition of sunflower husk reduces the formation of 2,3,7,8-polychlorinated dibenzo-para-dioxin and polychlorinated dibenzofuran by about $10 \%$ (from 1 to $0.91 \mathrm{ng} / \mathrm{nm}^{3}$ ) [17]. In the case of replacing $20 \%$ of coke with charcoal, the emissions of dioxins decrease by about $33 \%$ [25, 26]. According to the study $[18,27]$, the use of charcoal obtained from straw and sawdust in quantities of 40,20 and 15 wt. $\%$, reduces $\mathrm{SO}_{2}$ emissions by 38,32 and $43 \%$, respectively, while $\mathrm{NO}_{\mathrm{x}}$ emissions are decreased by 27,18 and $31 \%$, respectively. Consequently, the biomass utilisation can reduce the fossil fuels consumption and reduce harmful emissions. However, the negative effect of replacing coke with biomass is in the increase of CO content in the sinter gas [28, 29]. Thus, the CO concentration in gas increases from $2.07 \%$ to $2.85-3.11 \%$ by volume for different types of biomass [27] and from 3.0 vol.\% to 5.0 vol.\% when using charcoal of different types, according 
to [26]. Solving this issue is possible by changing the amount of air entering the combustion zone of fuel.

It is particularly noteworthy that the biomass application in metallurgy is known to reduce the formation of $\mathrm{CO}_{2}$ from fossil fuel. This effect is especially important in terms of the impact of metallurgical processes on climate change [30]. The primary attention is given to the report by Research Fund for Coal and Steel European Commission on the use of alternative carbon material in the sintering of iron ore [31]. The blast-furnace dust and slag, petroleum coke, anthracite, sunflower husks and olive stones are used as alternative fuels. According to the biomass research, the biomass fuel ground to the size smaller than the optimum size of coke breeze, contributes to the improvement of the temperature parameters of sintering, although the process performance and quality of the sinter are reported to be below that level when using coke breeze. Meanwhile, there is the main advantage of using biomass instead of a conventional fuel, it is the reduction of $\mathrm{SO}_{2}$ emissions and the improvement of the $\mathrm{CO}_{2}$ balance.

The purpose of the present work is to study the influence of alternative fuels, namely plant biomass, on the iron ore sintering process and the quality of the sinter produced; to analyse the differences in the sintering process with biomass application in comparison with those incorporating the conventional fuels such as coke and anthracite.

\section{Materials and Methods}

For the course of the experimental studies, the following materials have been selected for the research: iron ore, iron ore concentrate, coke breeze, limestone, lime, anthracite, walnut shell, sunflower husk and wood charcoal. The chemical composition of the blend materials is given in Table 1 while Table 2 presents the proximate analysis of the fuels applied for the study.

Table 1 Chemical Composition of the Blend Materials (wt.\%)

\begin{tabular}{|c|c|c|c|c|c|c|c|c|c|}
\hline \multirow{2}{*}{ Materials } & \multicolumn{8}{|c|}{ Content } \\
\cline { 2 - 11 } & $\mathrm{Fe}_{\text {total }}$ & $\mathrm{FeO}$ & $\mathrm{Fe}_{2} \mathrm{O}_{3}$ & $\mathrm{SiO}_{2}$ & $\mathrm{Al}_{2} \mathrm{O}_{3}$ & $\mathrm{CaO}$ & $\mathrm{MgO}$ & $\mathrm{LOI}^{1}$ & $\begin{array}{c}\text { Other } \\
\text { oxides }\end{array}$ \\
\hline $\begin{array}{c}\text { Iron ore } \\
\text { concentrate }\end{array}$ & 65.88 & 28.27 & 62.71 & 6.44 & 0.30 & 0.17 & 0.26 & 1.85 & - \\
\hline Iron ore & 57.75 & 1.76 & 80.54 & 12.71 & 1.60 & 1.72 & 0.62 & 1.82 & 0.47 \\
\hline Limestone & 0.28 & - & 0.40 & 1.5 & 0.56 & 48.5 & 0.92 & 43.56 & - \\
\hline Lime & 12.66 & - & 18.09 & 1.8 & 26.61 & 86.8 & 1.40 & & - \\
\hline
\end{tabular}

${ }^{1} \mathrm{LOI}-$ loss on ignition at $950{ }^{\circ} \mathrm{C}$ in air atmosphere.

Table 2 Proximate Analysis of the Fuels (wt.\%)

\begin{tabular}{|c|c|c|c|c|c|}
\hline Materials & $\begin{array}{c}\text { Moisture, } \\
\mathbf{W}^{\mathbf{a}}\end{array}$ & $\begin{array}{c}\mathbf{A s h} \\
\mathbf{A}^{\mathbf{d}}\end{array}$ & $\begin{array}{c}\text { Volatile Matter, } \\
\mathbf{V}^{\mathbf{d}}\end{array}$ & $\begin{array}{c}\text { Total Sulphur, } \\
\mathbf{S}_{\mathbf{t}}^{\mathbf{d}}\end{array}$ & Fixed Carbon \\
\hline $\begin{array}{c}\text { Coke } \\
\text { breeze }\end{array}$ & 15.1 & 15.3 & 1.5 & 1.2 & 82.0 \\
\hline Anthracite & 2.0 & 12.2 & 8.7 & 1.8 & 77.3 \\
\hline Charcoal & 3.3 & 3.7 & 12.5 & - & 83.8 \\
\hline $\begin{array}{c}\text { Walnut } \\
\text { shell }\end{array}$ & 7.2 & 0.3 & 75.6 & 0.2 & 23.9 \\
\hline $\begin{array}{c}\text { Sunflower } \\
\text { husk }\end{array}$ & 8.0 & 2.6 & 73.0 & - & 24.4 \\
\hline
\end{tabular}


From Table 2 it is obvious that the biomass analysed is characterised by a high content of volatile matter, but low ash content and almost no sulphur. It is worth noting that the largest fixed carbon content is a distinguishing feature of the charcoal.

The initial blend composition corresponded to the industrial blend. The content (in wt.\%) of iron ore concentrate in the blend was 46.75 , iron ore -10.5 , limestone -10.25 , lime -1.5 and coke breeze -6 . The amount of the return applied in the blend for the sample preparation was $25 \mathrm{wt} . \%$. In the case of using auxiliary fuel, the amount of fuel consumption has been calculated based on the fixed carbon and therefore different from the coke breeze.

The auxiliary fuels were used in individual form, as well as in mixtures with coke breeze in the following ratio (wt.\%): 25/75, 50/50 and 75/25. Table 3 shows the actual amount of the fuel in the blend $(\mathrm{g})$, depending on the type of the material used when rounding the nearest whole number. For sintering process used $2 \mathrm{~kg}$ pelletized blend.

Table 3 The fuel amount in the sintering blend.

\begin{tabular}{|c|c|c|c|c|c|}
\hline $\begin{array}{c}\text { The ratio of the } \\
\text { material in the } \\
\text { fuel (wt.\%) }\end{array}$ & \multicolumn{5}{|c|}{ Fuel type and quantity (g) } \\
\cline { 2 - 6 } & Coke breeze & Anthracite & Charcoal & Walnut shell & Sunflower husk \\
\hline 100 & 120 & 127 & 117 & 205 & 204 \\
\hline 75 & 90 & 96 & 88 & 154 & 153 \\
\hline 50 & 60 & 64 & 59 & 103 & 102 \\
\hline 25 & 30 & 32 & 29 & 51 & 51 \\
\hline
\end{tabular}

The materials were weighed, mixed, moistened, mixed again and pelletized in the pelletizer of the drum type. The water consumption for each sintering process with coke breeze was $7 \mathrm{wt} \%$, while in sintering experiments with other fuels the value of water varied, depending on the moisture content of the fuel. The pelletized blend was placed into the sintering pot equipped with a grate pre-wrapped in a bed of sinter with the fraction of $10-5 \mathrm{~mm}$.

The sintering experiments were performed as described below. The initial underpressure was approximately $5 \mathrm{kPa}$. It should be noted that not in all cases the sintering process started exactly at the specified underpressure. This was due to the significant variations in the gas permeability of the blend column when using different types of fuel. Subsequently, in $60 \mathrm{~s}$, the fuel ignition occurred to start the sintering process, and the ignition temperature was $1250{ }^{\circ} \mathrm{C}$. During the sintering process, the temperature of the exhaust gases and pressure under the grate were controlled. Sintering was completed when the temperature of the exhaust gases reached the maximum and began to decrease. After the sintering process, the study of the obtained sinter was carried out. The abrasive strength and the impact strength indicators have been determined as the percentage of the content of the sinter fraction after the destructive load of less than $0.5 \mathrm{~mm}$ and more than $5 \mathrm{~mm}$, respectively.

\section{Results and Discussion}

According to the results obtained with the sintering experiments, the main indicators of the sintering process, namely, the sinter quality and the specific capacity have been calculated. The changes in the pressures under the grate during the sintering process are shown in Fig. 1. In the Figures presented below anthracite, charcoal, walnut shell (WSH) or sunflower husk (SFH) are analysed individually in each case but referred generally as fuel. 


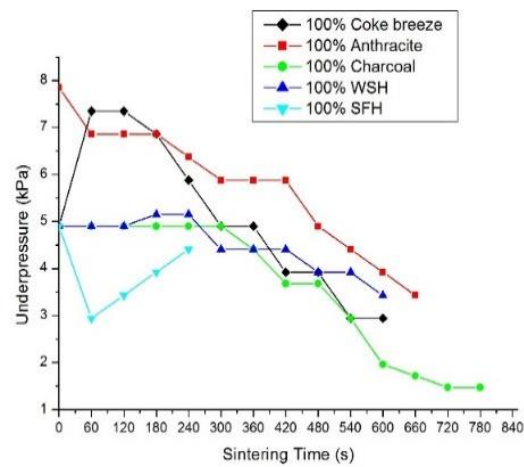

(a)

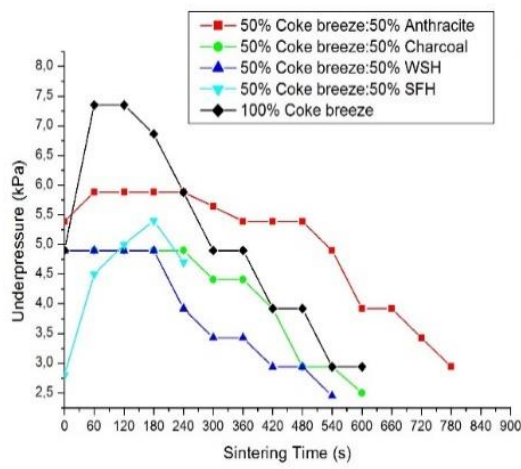

(b)
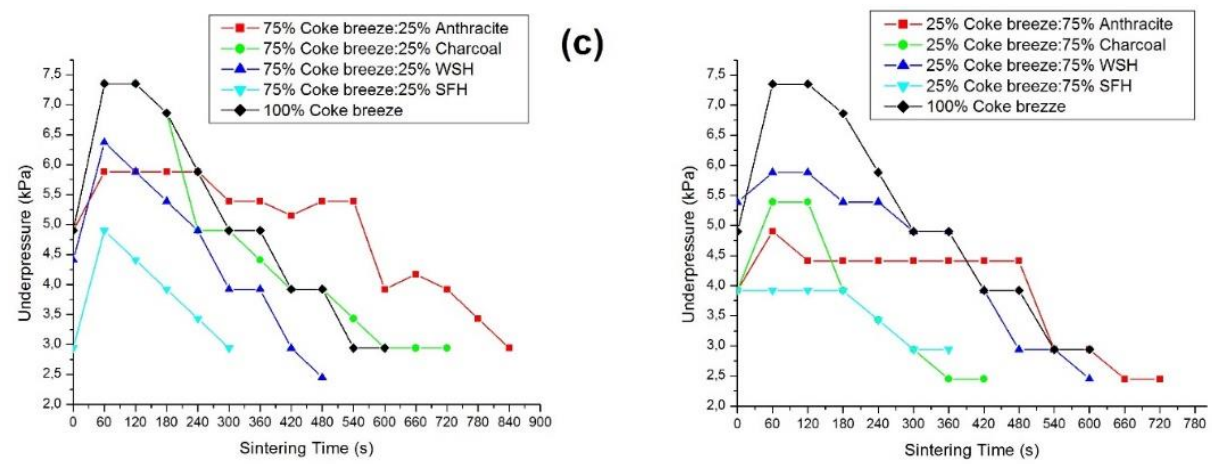

(d)

(c)

Fig. 1 (a) Changing the underpressure in the case of using $100 \%$ fuel; (b) Changing the underpressure in the case of using $50 \%$ of coke breeze plus $50 \%$ fuel; (c) Changing the underpressure in the case of using $75 \%$ of coke breeze plus $25 \%$ fuel; (d) Changing the underpressure in the case of using $25 \%$ of coke breeze plus fuel $75 \%$.

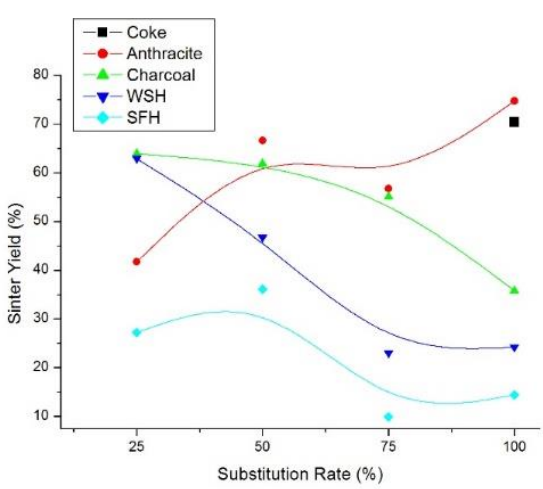

Fig. 2 Dependence of the sinter yield on the fuel type

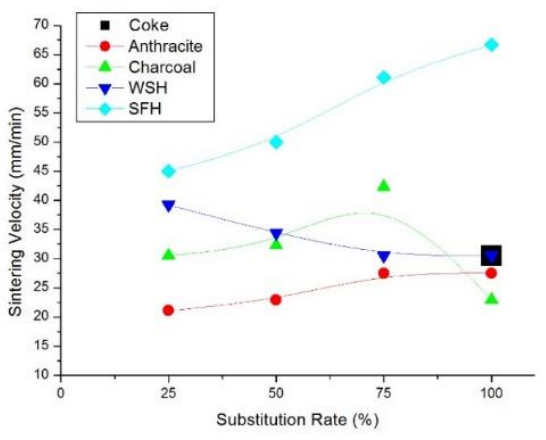

Fig. 3 Dependence of the sintering velocity on the type of fuel

As it can be seen, the addition of biomaterials to the sintering blend leads to an increase in the permeability of the sintered layer. This is due to the fact that the particles of biomaterials are located between the granules of the blend and increase the open porosity of the layer. 
The dependences of the sinter yield and the sintering velocity on the biomaterial content are shown in Fig. 2 and Fig. 3. Considering the influence of different types of solid fuels on the required sinter yield $(+10 \mathrm{~mm})$, its significant variations from $10 \%$ to $75 \%$ are noticeable. The lowest values have been obtained with the use of sunflower husks and walnut shell. The lowest values for sunflower husks can be explained by very low bulk density.

The results of measuring the bulk density of the biomaterials in comparison with anthracite and coke breeze are given in Table 4.

Table 4 Bulk Density of Fuels

\begin{tabular}{|c|c|}
\hline Type of fuel & Bulk density, $\mathbf{~ k g} / \mathbf{m}^{\mathbf{3}}$ \\
\hline Sunflower husk & 200 \\
\hline Walnut shell & 320 \\
\hline Charcoal & 285 \\
\hline Coke breeze & 340 \\
\hline Anthracite & 620 \\
\hline
\end{tabular}

In addition to reducing the bulk density of the blend, with increasing amounts of biomaterials, the reactivity of the fuel increases. However, the sintering velocity also varies depending on the distribution of fuel in the blend and its size.

The indicators of sintering velocity increased dramatically when sunflower husks were used. The maximum temperature of the exhaust gases was $200-280^{\circ} \mathrm{C}$. This evidences the low temperature regime of the sintering process. Additionally, this is due to the shorter burning time of the biomaterials particles compared with coke and anthracite particles. Mnykh et al. [32] considered the change in the burning time of anthracite and coke particles in term of the dependence on their size and reported that for the standard size of fuel particles the combustion time of the coke breeze was 48-52 s and for the anthracite it was 72-76 s during sintering. However, in our experiments for the sunflower husks with the sizes up to $3 \mathrm{~mm}$, the time of combustion did not exceed $40 \mathrm{~s}$. As a result, it did not allow providing the required temperature for the sintering process. Consequently, in the case of lowering the temperature of the process, the amount of primary ore in the sinter increased, which led to the decrease in the content of hematite formed during the secondary oxidation of magnetite.

The low combustibility of anthracite enabled the incomplete consumption of fuel during the sintering process, namely, the amount of the residual carbon in the sinter made $10 \%$ of its initial content in the blend.

Fig. 4 shows the change in the specific capacity of the sintering pot, depending on the biomaterials content in the blend. It is known that the specific capacity of a sintering pot depends on the sinter yield and the sintering velocity. However, Fig. 4 shows that despite the increase in the sintering velocity, the addition of biomaterials reduces the specific capacity of the sintering pot by reducing the sinter yield. Based on the results have been obtained and the above-mentioned information, we conclude that the substitution rate for charcoal or walnut shells is suitable as much as $25 \%$. In the case of using sunflower husks, the required specific capacity could not be reached in the sintering process. Therefore, this biomaterial requires preliminary preparation if there is the need for its further application in the iron ore sintering. 


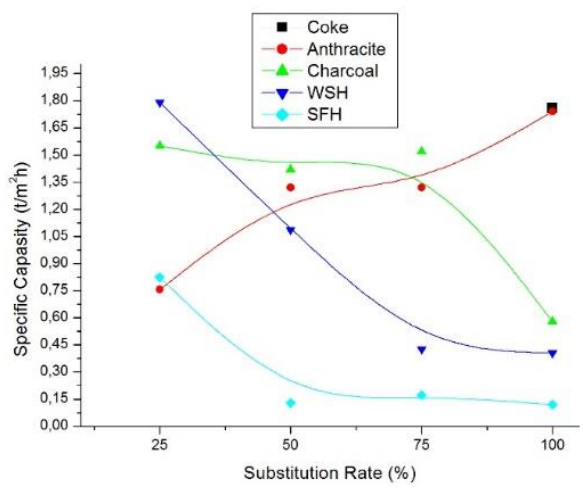

Fig. 4 Dependence of the specific capacity on the fuel type

Fig. 5 shows the strength of the sinter for impact (a) and abrasion (b) but with sunflower husks. In this set of the experiments, we did not conduct any strength tests with the sinter obtained via the sunflower husks incorporations due to the very low sinter yield with this fuel though for the other experimental fuels the results are submitted below.
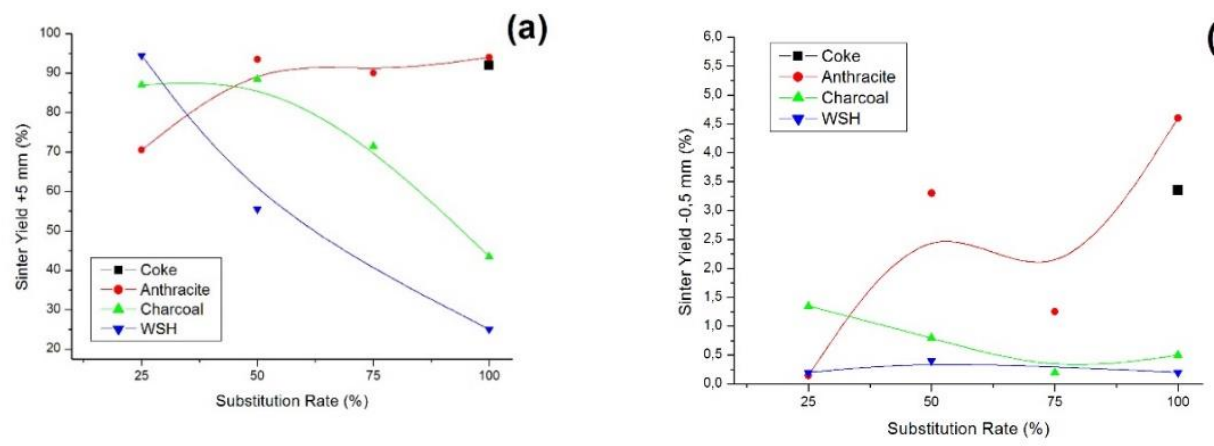

Fig. 5 (a) Dependence of the sinter impact strength on the fuel type; (b) Dependence of the sinter abrasion strength on the fuel type

The substitutive application of more than $50 \%$ of charcoal or more than $25 \%$ of walnut shell in the fuel causes the dramatic adverse effect produced on the resulting sinter impact strength due to the increasing porosity within the sinter. At the same time, these substitution rates allow sinter to possess the abrasion strength value and to exceed the values of coke breeze and anthracite.

Eventually, based on the results of an experimental study of the alternative fuels influence on the basis of plant biomass in the iron ore sintering process and the quality of the obtained sinter, it has been established that charcoal or walnut shell can be used in the amount of $25 \%$. The sunflower husk utilisation is possible by pre-conditioning this material to increase its bulk density, for instance, by pressing.

\section{Conclusions}

The review in this work shows the possibilities of efficient biomass utilisation in the process of iron ore sintering. Such approach is able to improve the production and the environmental aspects 
of the process. Due to the preparation and further application of the biomass with certain characteristics, it is possible to improve the thermal parameters of the sintering process, to increase the process productivity and to obtain sinter with the desired quality. The study on the influence of various biomaterials types on iron ore sintering process and the obtained sinter quality, in comparison with the conventional types of the fuels, allow establishing the feasibility of replacing $25 \%$ of coke breeze by charcoal or the walnut shell. The use of the biofuels in such a ratio to the coke breeze enables sustaining the process efficiency and sinter strength at the required level.

The key characteristic of the biomaterials applied as a fuel for sintering is the bulk density, which determines the thermal parameters of the process, and the sinter structure. Therefore, in order to improve the technological indicators of the sintering process with biofuels utilisation, the preliminary preparation of biomaterials should be carried out with the purpose to increase their bulk density. Thus, the effective sunflower husk application is possible only with its preliminary preparation. Finally, the promising direction of improving the sintering technology with the biomaterials utilisation is the use of separate pelletizing methods.

\section{References}

[1] World Steel Association. Short Range Outlook, 2018, [06.02.2019], Available online: https://www.worldsteel.org/media-centre/press-releases/2018/worldsteel-Short-RangeOutlook-2018-2019.html

[2] Ukraine's promising market segments for heating with solid biomass (> $100 \mathrm{~kW}$ ), [15.02.2019], Available online: http://www.bioenergy4business.eu/wpcontent/uploads/2015/06/B4B-WP2_Country_Summary_Report_Ukraine_13-08-2015.pdf.

[3] Biofuel use in Ironmaking from a Life Cycle Analysis Perspective, [15.02.2019], Available online: http://cancarb.ca/pdfs/CCRA_papers/AISTech2011_Biofuel\%20LCA.pdf

[4] P. Chudíková, M. Taušová, K. Erdélyiová, P. Tauš: Acta Montanistica Slovaca, Vol. 15, No. 2, 2011, p. 139-145, (in Slovak)

[5] P. Tauš, M. Taušová, P. Horbaj, K. Čulková, J. Koščo: Economic evaluation of boiler for biomass using in Slovakia, In.: International Multidisciplinary Scientific GeoConference Surveying Geology and Mining Ecology Management, SGEM, Vol. 1, 2015, No. 4, p. $167-174$

[6] Bioenergy instead of gas., [06.02.2019], Available online: http://www.epravda.com.ua/publications/2015/01/9/520368/, (in Ukrainian)

[7] H. Heletukha, S. Drahniev, P. Kucheruk, Y. Matvieiev: Practical manual on the biomass utilisation as a fuel in the municipal sector of Ukraine (for representatives of the agroindustrial complex), Agency for Renewable Energy, Kyiv, Ukraine, 2017, (in Ukrainian).

[8] E. Mousa, C. Wang, J. Riesbeck, M. Larsson: Renewable and Sustainable Energy Reviews, Vol. 65, 2016, p. 1247-1266, DOI: 10.1016/j.rser.2016.07.061

[9] R. Wei, L. Zhang, D. Cang, J. Li, X. Li, C.C. Xu: Renewable and Sustainable Energy Reviews, Vol. 68, 2017, No. 1, p. 511-524, DOI: 10.1016/j.rser.2016.10.013

[10]H. Suopajärvi, A. Kemppainen, J. Haapakangas, T. Fabritius: Journal of Cleaner Production, Vol. 148, 2017, p. 709-734, DOI: 10.1016/j.jclepro.2017.02.029

[11]C.M. Wiklund: Optimization of a steel plant utilizing converted biomass. PhD Thesis. Turku/Abo: Åbo Akademi University, Finland, 2016

[12] W. Wei, P. Mellin, W. Yang, C. Wang, A. Hultgren, H. Salman: Utilization of biomass for blast furnace in Sweden: biomass availability and upgrading technologies. Stockholm, 2013, Report I:1, DOI: 10.1016/j.egypro.2014.12.125 
[13]E. A. Mousa, H. M. Ahmed, N. N. Viswanathan, M. Larsson: Recent trends in ironmaking blast furnace technology to mitigate $\mathrm{CO}_{2}$ emissions: tuyeres injection. In.: Ironmaking and steelmaking processes, edited by P. Cavaliere, Springer, Switzerland, 2016, p. 173-197, DOI: 10.1007/978-3-319-39529-6

[14]H. Suopajarvi: Bioreducer use in blast furnace ironmaking in Finland. PhD Thesis, Oulu University, Oulu, 2014

[15]H. Helle, M. Helle, H. Saxén, F. Pettersson: ISIJ International, Vol. 49, 2009, No. 9, p. 1316-1324, DOI: 10.2355/isijinternational.49.1316

[16] K.W. Ng, W.P. Hutny, J.A. MacPhee, J.F. Grandsen, J.T. Price: Bio-fuels use in blast furnace ironmaking to mitigate GHG emission. In.: 16th European Biomass Conference and Exhibition, Valencia, Spain, June 2-6, 2008

[17]T. Ch. Ooi et al.: Miner Eng, Vol. 21, 2008, p. 167-177, DOI: 10.1016/j.mineng.2007.09.005

[18] M. Gan: Fundamental research on iron ore sintering with biomass energy. PhD Thesis. Changsha: Central South University, Hunan, 2012

[19] M. Zandi, M. Martinez-Pacheco, T.A.T. Fray: Minerals Engineering, Vol. 23, 2010, No. 14, p. 1139-1145, DOI: 10.1016/j.mineng.2010.07.010

[20]R. Lovel, K. Vining, M. Dell'Amico: Mineral Processing and Extractive Metallurgy Review, Vol. 116, 2007, No. 2, p. 85-92, DOI: 10.1179/174328507X163887

[21]G. Liu et al.: Chemosphere, Vol. 89, 2012, No. 4, p. 467-472, DOI: 10.1016/j.chemosphere.2012.05.101

[22] C. Mo, C. Teo, I. Hamilton, J. Morrison: ISIJ International, Vol. 37, 1997, No. 4, p. 350-357, DOI: $10.2355 /$ isijinternational.37.350

[23] Y.S. Mok, I. Nam: IEEE Transactions on Plasma Science, Vol. 27, 1999, No. 4, p. 1188-1196, DOI: 10.1109/27.782299

[24]Y. Chen et al.: Chemosphere, Vol. 88, 2012, No. 11, p. 1324-1331, DOI: $10.1016 /$ j.chemosphere.2012.05.031

[25] T. C. Ooi, D. Thompson, D. R. Anderson, R. Fisher, T. Fray, M. Zandi: Combustion and Flame, Vol. 158, 2011, No. 5, p. 979-987, DOI: 10.1016/j.combustflame.2011.01.020

[26] T. Kawaguchi, M. Hara: ISIJ International, Vol. 53, 2013, No. 9, p. 1599-1606, DOI: $10.2355 /$ isijinternational.53.1599

[27]M. Gan et al.: ISIJ International, Vol. 52, 2012, No. 9, p. 1574-1578, DOI: $10.2355 /$ isijinternational.52.1574

[28] J. G. M. S. Machado, E. Osório, A. C. F. Vilela, A. Babich, D. Senk, H. W. Gudenau: Steel Research International, Vol. 81, 2010, No. 1, p. 9-17, DOI: 10.1002/srin.200900093

[29]L. Lu et al.: ISIJ International, Vol. 53, 2013, No. 9, p. 1607-1616, DOI: $10.2355 /$ isijinternational.53.1607

[30] T. Norgate, N. Haque, M. Somerville, S. Jahanshahi: ISIJ International, Vol. 52, 2012, No. 8, p. 1472-1481, DOI: $10.2355 /$ isijinternational.52.1472

[31] European Commission. EUR 25151. Alternate carbon sources for sintering of iron ore (Acasos), Research Fund for Coal and Steel, Luxembourg, Publications Office of the European Union, 2013, DOI:10.2777/58105

[32] A. S. Mnykh, I. G. Yakovleva, M. Yu. Pazyuk: Energy Saving Power Engineering Energy audit, Vol. 10, 2015, p. 56-63, (in Russian) 


\section{Acknowledgements}

This research was funded by the Ministry of Education and Science of Ukraine, grant number 0117U003919. Additionally, the authors would like to acknowledge Prof. Arkadii Tarakanov, Head of Department of Iron Metallurgy, National Metallurgical Academy of Ukraine for his kind support in carrying out this work. 